Volume 6 Issue 1, March 2021:pp. 12-25 Copyright @ LamLaj. Faculty of Law, Lambung Mangkurat University, Banjarmasin, South Kalimantan, Indonesia. ISSN: 2502-3136 | e-ISSN: 2502-3128. Open Access at: http://lamlaj.ulm.ac.id/web/

\title{
CONSTRUCTION OF LEGAL EDUCATION IN COLLEGE EDUCATION THROUGH PANCASILA EDUCATION
}

\author{
Nufikha Ulfah ${ }^{1}$, Endrik Safudin' ${ }^{2}$, Yayuk Hidayah ${ }^{3}$
}

${ }^{1} M K U$ Pendidikan Pancasila dan Kewarganegaraan

Teknologi Infrastruktur dan Kewilayahan Institut Teknologi Sumatera (ITERA)

Jl. Terusan Ryacudu, Way Huwi, Lampung, Indonesia 35365

Email:nufikha.ulfah@staff.itera.ac.id

${ }_{2}^{2}$ Institut Agama Islam Negeri Ponorogo

Jl. Pramuka No. 156, Ponorogo, Indonesia 461893

Email :endrisafudin@gmail.com

${ }^{3}$ Universitas Ahmad Dahlan

Jl. Kapas No.9, Semaki, Daerah Istimewa Yogyakarta, Indonesia 55166

Email :yayuk.hidayah@pgsd.uad.ac.id

Submitted : 04/10/2020 Reviewed:18/01/2021 Accepted:09/02/2021

Abstract: Legal awareness is a noble ideal when juxtaposed with the realization of smart and good citizens in Indonesia. This study aims to interpret, systematically identify efforts to build legal awareness in Higher Education. The research method used in this research is the Mixed Method. The data were obtained from a questionnaire given to 116 students from the non-law department and non-PPKn department at Ahmad Dahlan University, Yogyakarta. The results showed that 1) Building legal awareness through the substance of Pancasila Education material, 2) Student opinion about building legal awareness and law-abiding behavior was that 79\% said it was enough, 12\% was not optimal. 3) The relevance of Pancasila Education material with efforts to build legal awareness is Pancasila as an ethical system, Pancasila as a philosophical system, the practice of Pancasila, Pancasila as the state ideology, 4) Assessment in Pancasila education is through tests, observations, assignments and projects.

Keywords: Rule of Law; College; Citizen

DOI : 10.32801/lamlaj.v6i1.199

\section{INTRODUCTION}

A good state is a country that has a sovereign constitution. Because, ideological intelli- gence for citizens will strengthen unity ${ }^{1}$. Law

Yayuk Hidayah, Meiwatizah Trihastuti, and Dinie Anggraeni Dewie, "Kecerdasan Berideologi Calon 
is formed as a social institution to regulate the rights and obligations of all elements in state life and must be obeyed. In this context, the essence of the formation of a State is to ensure the creation of peace in people's lives ${ }^{2}$. Soekanto added that one of the functions of law is as a means of reforming society. Today development in Indonesia includes material and spiritual aspects of people's lives which include the realms of work, creativity and taste, by paying attention to legal awareness in society. Therefore, legal awareness and legal compliance need to be discussed in a development framework which is a process of planned and directed change. Soerjono Soekanto emphasized that in this case the law functions as a means of social control and a means of bringing about change ${ }^{3}$.

The law, which should be seen as an important aspect in creating security and order in society, is precisely what some people ignore, including today's youth. Law is not uncommon often injured, violated, even manipulated. Currently, lawlessness is a frightening specter in Indonesia. The decline in legal awareness can be seen from the violations of the law and disobedience to the law itself. Ironically, those who violate the law are not people who do not know the law, they are people who know about the law.

A study on the decline in legal awareness

Guru Pendidikan Sekolah Dasar Melalui Pendidikan Pancasila," Jurnal Al - Qiyam 1, no. 2 (2020): 74, https://journal.stai-alfurqan.ac.id/alqiyam/index.php/ alqiyam/article/view/25.

2 Lukman Santoso Az, Negara Hukum Dan Demokrasi: Pasang Surut Negara Hukum Indonesia Pasca Reformasi, ed. Yutisa Tri Cahyani, Cetakan I (Ponorogo: IAIN Po PRESS, 2016), 7.

3 Soerjono Soekanto, "Kesadaran Hukum Dan Kepatuhan Hukum," Jurnal Hukum Dan Pembangunan 7, no. 6 (1977) : 462-470, http://jhp. ui.ac.id/index.php/home/article/view/742 of the Indonesians resulted in the conclusion that to increase legal awareness in the community, counseling on legal awareness at the school and tertiary level is needed, besides that law enforcement officials can also provide examples in solving legal problems so that legal awareness can emerge ${ }^{4}$. Other research on the legal awareness of PPKn FPIPS UPI students class of 2014 in using the Internet shows that students' understanding of the Law of the Republic of Indonesia Number 11 of 2008 is still low. In this study, several factors were found that affect students' legal awareness of the Law of the Republic of Indonesia Number 11 of 2008, namely socialization, repression and self-awareness ${ }^{5}$. A study of students 'legal awareness of technology and its development resulted that students' understanding of the Information and Electronic Transactions Law was diverse ${ }^{6}$. Other studies regarding the urgency of legal education have resulted that legal education is important in raising public awareness of the law, the need for a critical review of the content and methods of legal education, an effective legal education model is participa-

\footnotetext{
4 Puji Wulandari Kuncorowati, "Menurunnya Tingkat Kesadaran Hukum Masyarakat di Indonesia," Jurnal Civics Media Kajian Kewarganegaraan 4, no. 2 (2009): 74-75, https://journal.uny.ac.id/index.php/ civics/article/view/5678

5 Dedi Ahmad Jubaedi, “Kesadaran Hukum Mahasiswa Terhadap UU RI No. 11 Tahun 2008 Tentang Informasi Dan Transaksi Elektronik Dalam Penggunaan Internet" (Fakultas Pendidikan Ilmu Pengetahuan Sosial Universitas Pendidikan Indonesia, 2016), http://repository.upi.edu/26460/.

6 Layyin Mahfiana, "Kesadaran Hukum Mahasiswa Terhadap Teknologi Dan Perkembangannya," in Prosiding Seminar Nasional \& Temu Ilmiah Jaringan Peneliti IAI Darussalam Blokagung Banyuwangi (Banyuwangi: IAI Darussalam Blokagung Banyuwangi, 2017), 1-13, http://ejournal.iaida.ac.id/ index.php/proceeding/article/view/179.
} 
tory ${ }^{7}$. Furthermore, research on students' legal awareness of smoke-free areas at the State University of Surabaya, resulted that the legal awareness of undergraduate students regarding smoking-free areas at the State University of Surabaya was in the low category. campus environment, supervision and guidance ${ }^{8}$. The findings of this study provide an overview of the importance of legal awareness. Furthermore, there has been no research that raises the issue of fostering legal awareness through Pancasila Education in Higher Education. Thus, this research is expected to be able to complete the void of research space.

The formulation of the research problem is to obtain information on how to build legal awareness through Pancasila Education in Higher Education; parse student opinions about efforts to build legal awareness through Pancasila Education in Higher Education; knowing the relevance of Pancasila Education material as an effort to build legal awareness in Higher Education; and get information about student assessments of Pancasila Education learning as an effort to build legal awareness in Higher Education.

The general purpose of this study is to determine the role of Pancasila Education as an effort to build legal awareness in Higher Education. While the specific objectives are first, to get an overview of student opinions

\footnotetext{
7 Sumaryati, "Urgensi Pendidikan Hukum Dalam Mewujudkan Kesadaran Hukum Masyarakat," in Konferensi Kewarganegaraan (Yogyakarta: Universitas Negeri Yogyakarta, 2015), 1-13, http:// eprints.uad.ac.id/8071/.

${ }^{8}$ Heru Setyawan and Indri Fogar Susilowati, "KESADARAN HUKUM MAHASISWA TERHADAP ATURAN TENTANG AREA KAWASAN TANPA ROKOK (Studi Di Kampus Universitas Negeri Surabaya)," Novum: Jurnal Hukum 5, no. 3 (2018): 48-55, https://ejournal.unesa. ac.id/index.php/novum/article/view/36058.
}

about efforts to build legal awareness through Pancasila Education in Higher Education. Second, knowing the relevance of Pancasila Education material as an effort to build legal awareness in Higher Education. Third, describe student assessments of Pancasila education learning as an effort to build legal awareness in Higher Education.

As for the benefits of theoretical research, namely being able to contribute ideas for the renewal of the study of legal awareness through Pancasila education in Higher Education and as a consideration for the development of Pancasila education in Higher Education as an effort to build legal awareness for students. Practical benefits for students are beneficial for the development of legal awareness through Pancasila Education in Higher Education. For academics and practitioners of Pancasila education, it is beneficial for improving the quality and fostering of Pancasila Education materials related to efforts to build legal awareness. In addition, the results of this study are expected to be a consideration in the preparation of appropriate learning programs in increasing legal awareness through Pancasila Education in Higher Education.

\section{Literature Review \\ Concepts of Legal Equality}

In the world of Psychology, awareness is a topic that has various definitions of consciousness ${ }^{9}$. KBBI translates awareness as conversion; state of understanding ${ }^{10}$. Meanwhile, another definition of awareness is defined as an attitude or behavior to understand

\footnotetext{
${ }^{9}$ Dicky Hastjarjo, "Sekilas Tentang Kesadaran (Consciousness)," Buletin Psikologi 13, no. 2 (2015): 79-90, https://jurnal.ugm.ac.id/buletinpsikologi/ article/view/7478

${ }^{10}$ Ebta Setiawan, "KBBI Online," Badan Pengembangan Dan Pembinaan Bahasa, last modified 2012, https:// kbbi.web.id/sadar.
} 
the customary rules and habits of life that exist in society ${ }^{11}$. Furthermore, Mica R Endsley in the book Situational Awareness chapter 2 provides an explanation that in order to achieve awareness it is first necessary to distinguish between situation awareness which can then be used to explain the terminology of awareness ${ }^{12}$. Thus consciousness can be interpreted as a form of knowing, understanding about something that is in itself or the environment.

When viewed from a philosophical point of view, law is to study some human behavior by emphasizing the goals of order and freedom ${ }^{13}$

Austin in ${ }^{14}$ arguing that law is an order that comes from those who have the highest power. Austin explained that the law contains four elements, namely sanctions, obligations, sovereignty and orders. Meanwhile, Hans Kelsen defines law as a rule system, a system of human rules. The law is not a single rule but a set of rules ${ }^{15}$. If so, it can be concluded that the law is a set of rules aimed at creating safe conditions for society.

The next question is whether in translating legal awareness can we start with understanding about awareness and law? In this connection, after knowing awareness, the law

\footnotetext{
${ }^{11}$ AW. Widjaja, Kesadaran Hukum Manusia Dan Masyarakat Pancasila (Jakarta: CV.Era Swasta, 1982).

${ }^{12}$ Mica R Endsley, "Situational Awareness," in Situational Awareness ed. Eduardo Salas. (London: Routledge, 2011).

${ }^{13}$ Benediktus Hestu Cipto Handoyo, Hukum Tata Negara Indonesia. (Yogyakarta: Universitas Atma Jaya, 2009).

${ }^{14}$ Satjipto Raharjo, Ilmu Hukum (Bandung: PT. Citra Aditya Bakti., 2000).

${ }^{15}$ Jimly Asshiddiqie and M. Ali Safa'at, Teori Hans Kelsen Tentang Hukum, Cetakan I, (Jakarta: Sekretariat Jenderal dan Kepaniteraan Mahkamah Konstitusi, 2006), 13
}

in translating legal awareness can become a sense that can sharpen the analysis of legal awareness. Legal awareness is an awareness of the values in humans regarding law. Emphasis of legal awareness is on the function of law, not on legal judgments of certain events ${ }^{16}$. In the dimension of legal awareness, $\mathrm{it}^{17}$ classifies that legal awareness has two dimensions, namely affective and cognitive. Affective includes recognizing that the law must be obeyed and cognitive is knowledge about the law which contains behavior that is prohibited and ordered according to the specified law. Law is the hope of what is aspired to achieve order in society. In legal awareness, there are several indicators, Kutschincky ${ }^{18}$ provides several indicators in legal awareness, namely 1) legal knowledge 2) knowledge of the content of legal regulations 3) attitudes towards the law 4) legal behavior patterns. Furthermore, Zainuddin Ali gave an explanation of several matters related to legal awareness, namely 1) knowledge of the content of legal regulations which includes public knowledge of laws that have been passed, 2) understanding of the law, namely understanding of legal objectives, 3) compliance with law, 4) expectations of the law and 5) increasing legal awareness ${ }^{19}$. In reasoning about legal awareness, actions can be separated from legal objectives. The purpose of law is to protect ev-

\footnotetext{
${ }^{16}$ Soerjono Soekanto, Sosiologi : Suatu Pengantar. (Jakarta: CV Rajawali., 1982).

${ }^{17}$ Iwan Zainul Fuad, "Kesadaran Hukum Pengusaha Kecil Di Bidang Pangan Dalam Kemasan Di Kota Semarang Terhadap Regulasi Sertifikasi Produk Halal" (Magister Ilmu Hukum Universitas Diponegoro, 2010), http://eprints.undip.ac.id/23888/.

${ }^{18}$ Soekanto, Sosiologi : Suatu Pengantar.

${ }^{19}$ Zainuddin Ali, Filsafat Hukum (Jakarta: Sinar Grafika., 2007).
} 
ery human being and society as a whole. ${ }^{20}$ In community life, legal awareness needs to be fostered so that people can be more obedient and obedient to the laws both written and developed in the community. ${ }^{21}$

\section{METHOD}

This research uses a mixture of quantitative and qualitative methods. Mixed methods are research that combines quantitative and qualitative. ${ }^{22}$ This research begins by giving a questionnaire to students of non-law majors and students of non-PPKn majors. Then the results of the questionnaire are analyzed using quantitative and qualitative approaches. The research subjects were selected by purposive sample using categories that have been determined by the researcher, namely students of the non-law department and students of the non-PPKn department.

Overall the number of questionnaire questions was 18 statements covering indicators of legal awareness and indicators of law-abiding behavior. The emphasis in this research is qualitative then supported by quantitative data.

Qualitative data collection was carried out by interview, observation and documentation. Interviews were conducted with students from the non-law department and students from the non-PPKn department who were randomly selected. The interview guide used included

\footnotetext{
${ }^{20}$ Widjaja, Kesadaran Hukum Manusia Dan Masyarakat Pancasila.

${ }^{21}$ Ellya Rosana, "Kepatuhan Hukum sebagai Wujud Kesadaran Hukum Masyarakat," Jurnal Tapis: Jurnal Teropong Aspirasi Politik Islam 10, no. 1 (2014):2 , http://ejournal.radenintan.ac.id/index.php/TAPIs/ article/view/1600.

${ }^{22}$ John W Creswell, Research Design: Pendekatan Kualitatif, Kuantitatif, Dan Mixed. (Yogyakarta: PT Pustaka Pelajar, 2010).
}

questions about:

1. How to build legal awareness and lawabiding behavior through Pancasila Education in Higher Education?

2. What are the opinions of students about building legal awareness and law-abiding behavior through Pancasila Education in Higher Education?

3. How is the relevance of Pancasila Education in Higher Education to efforts to build legal awareness and law-abiding behavior through Pancasila Education in Higher Education?

4. How is the assessment of Pancasila Education in Higher Education towards efforts to build legal awareness and law-abiding behavior through Pancasila Education in Higher Education?

The interviews lasted about 30-40 minutes with different locations. Researchers used recording devices and writing instruments to collect data during the interview.

The observations that researchers do are non-participant observations. Researchers seek to gather information about building legal awareness and law-abiding behavior without being part of the situation. Researchers only observe and take notes regarding the information obtained. The next qualitative data collection is through documentation. The documentation that researchers do is to collect files that support the development of legal awareness and law-abiding behavior in Higher Education. The files are in the form of field notes, journals, research results, reports, magazines, newspapers, minutes and other files that the researcher deems relevant to the research theme.

Quantitative data analysis used SPSS statistic 24. Meanwhile, qualitative data analysis used Miles and Huberman's model, namely 
data collection, data reduction and conclusion drawing ${ }^{23}$. Guidelines in data analysis are

1) the researcher collects the results of interviews, observations and documentation regarding legal awareness and law-abiding behavior then presented in the form of complete notes.

2) the researcher did data reduction, which is taking only the important points regarding legal awareness and law-abiding behavior.

3) from data reduction then the researcher arranges systematically in order to capture meaning.

4) the researcher draws conclusions from the presentation of the data.

5) the conclusions that have been obtained then continue to develop until they find conclusions that really fit.

\section{ANALYSIS AND DISCUSSION}

Legal Awareness and Law-Compliant Behavior of Students through Pancasila Education in Higher Education

Overall the description of respondents in this study is as shown in Figure 1 below:

Figure 1: Description of respondents

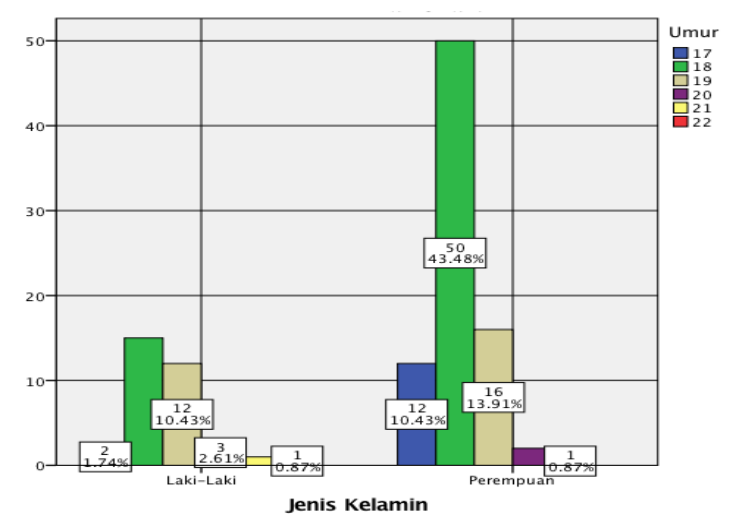

Source: Research Data, 2019

Research data findings are divided into quantitative findings and qualitative. In the

23 Ibid. results and discussion, the researcher collaborates directly between quantitative and qualitative findings. Broadly speaking, the findings and discussion are the answers to the four problem formulations in the form of, Building legal awareness through Pancasila Education in Higher Education. Student opinion about building legal awareness through Pancasila Education in Higher Education. The relevance of Pancasila Education material in Higher Education towards efforts to build legal awareness through Pancasila Education and Assessment in Pancasila education in tertiary institutions to efforts to build legal awareness. The results of the research findings are then processed and broken down in detail into the following discussion.

Building legal awareness and law-abiding behavior through Pancasila Education in Higher Education

Based on the results of a questionnaire that was distributed to 116 student respondents from the non-law department and nonPPkn students at Ahmad Dahlan University, Yogyakarta, it can be seen that the indicators of law-abiding attitudes and behavior get the highest score. higher compared to others, namely with a mean of 33.62 while the mean knowledge and understanding of law was 28.54. From quantitative the results, then the researchers add data through a process of qualitative interviews. The results of interviews with students from the non-law department and non-PPkn students at Ahmad Dahlan University, Yogyakarta, found that high scores in law-abiding attitudes and behavior of students were obtained through experience in emphasizing law-abiding attitudes and behavior that obey the law. The existence of law obedience in students so that they display law-abiding attitudes and behaviors is a 
form of cause and effect from awareness and law obedience. Law-abiding attitudes and behavior for students are obligations that must be carried out due to sanctions. This was expressed by EYS, one of the respondents who stated "... I think law-abiding attitudes and behaviors are the rules of life as social beings so that life can be harmonious. If attitudes and behavior do not obey the law, there will be negative views from our environment ... "The same thing was also expressed by KEL which said that ..." showing attitudes and behavior that obey the law is a sign that if you have obeyed the law and if it is not implemented it will get sanctions. It's complicated when talking about sanctions..."

Based on these findings, proving that the existence of sanctions in law is one of the things that the respondents emphasized. The role of law in society is to maintain patterns of behavior that prevail in society ${ }^{24}$. Knowledge and understanding of law is a factor in legal awareness. The legal awareness factor has a role in legal development ${ }^{25}$.

Students of the non-law department and non-PPKn department at Ahmad Dahlan University in Yogyakarta have carried out practices that support legal awareness in their daily lives. For more detailed results, it can be seen in table 1 below:

\footnotetext{
${ }^{24}$ Kamaruddin., "Membangun Kesadaran dan Ketaatan Hukum Masyarakat Perspektif Law Enforcement," Jurnal Al-'Adl 9, no. 2 (2016): 143-157, https:// ejournal.iainkendari.ac.id/index.php/al-adl/article/ view/683

${ }^{25}$ Zulkarnain Hasibuan, "Kesadaran Hukum Dan Ketaatan Hukum Masyarakat Dewasa Ini," Jurnal Justitia: jurnal Ilmu Hukum Dan Humaniora, 1, no. 1 (2013): 78-92, http://jurnal.um-tapsel.ac.id/index. $\mathrm{php} / \mathrm{Justitia} /$ article/view/40
}

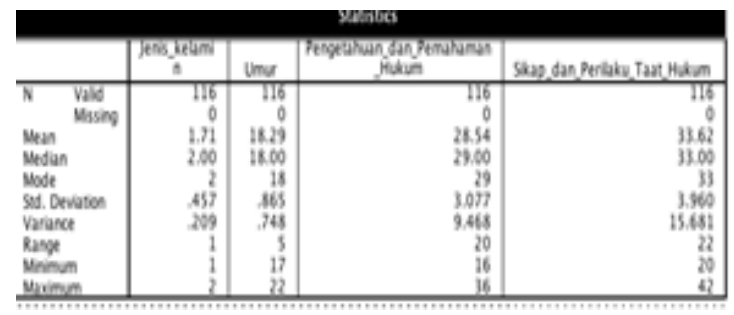

Source: Research Data, 2019

Learning Pancasila Education in Higher Education has a bonus of hope as supporting efforts to smart and good citizens ${ }^{26}$ realizeBuilding student legal awareness through Pancasila Education in Higher Education is through internalization Pancasila values. In realizing society, there are several influencing factors, namely knowledge of the contents of regulations in law, respect for legal provisions and law-abiding behavior. Through the internalization of Pancasila values in students, it can be a supplement in building legal awareness. In addition, in realizing a law-aware society there are several factors that influence, which is knowledge of the contents of the rules in law, respect for legal provisions and law-abiding behavior. From the quantitative results, then the researcher got additional data from interviews with first semester students of the Department ofLiterature Indonesianat Ahmad Dahlan University who stated that legal awareness and law-abiding behavior need to be nurtured continuously and not only in class. However, students admit that through Pancasila Education they can increase knowledge about legal awareness and law-abiding

\footnotetext{
${ }^{26}$ Nufikha Ulfah et al., "PROJECT CITIZEN: DEVELOPMENT OF SOCIAL SKILLS AND UNDERSTANDING OF CONTEMPORARY ISSUES (STUDY AT AHMAD DAHLAN UNIVERSITY)," Lentera Pendidikan : Jurnal Ilmu Tarbiyah dan Keguruan 23, no. 1 (2020): 9-21, http://journal.uin-alauddin.ac.id/index.php/lentera pendidikan/article/view/12520
} 
behavior.

Based on table 1, knowledge and understanding of law has a value of 29.00. Based on quantitative data, it can be understood that students of the non-law department and nonPPKn department at Ahmad Dahlan University, Yogyakarta have high knowledge and understanding of law. Culturally, Pancasila has cultural values of the personality of the Indonesian nation. Pancasila as moral literacy for the Indonesian nation (Dianasari \& Hidayah, 2019). Based on the results of interviews with lecturers who teach the General Compulsory Course of Pancasila at Ahmad Dahlan University, Yogyakarta, it is known that in efforts to enrich legal awareness through Pancasila courses, it is necessary to pay attention to several aspects that are grown in students, namely first awareness of equality before the law, second awareness to obey the applicable law. and third is that the existence of law is in order to achieve social harmony. The actualization of Pancasila values in the behavior of people who have legal awareness is emphasized on values about law and not trapped in legal judgments on concrete phenomena that exist in society. Law plays a role in maintaining rights and obligations in society ${ }^{27}$.

\section{Student opinion about building legal aware- ness and law-abiding behavior through Pancasila education in tertiary institutions}

Figure 2

Description of building legal awareness and lawabiding behavior through Pancasila Education in

Higher Education

\footnotetext{
${ }^{27}$ Endrik Safudin, Dasar-Dasar Ilmu Hukum (Malang: Setara Press, 2017).
}

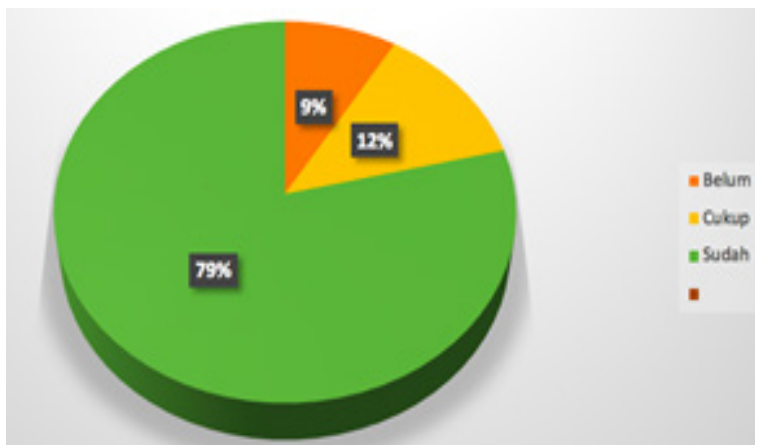

Source: Research Data, 2019

Based on data quantitative , $79 \%$ of students said that learning Pancasila Education in Higher Education it is sufficient to support in building awareness and law-abiding behavior, in their opinion they say that in learning Pancasila education does not escape discussing the rules that apply in everyday life, for example rules that must be obeyed at educational institutions, things that According to them, it is a valuable lesson for their daily lives and that legal awareness and behavior are points that must be implemented in the life of society and the state. A total of $9 \%$ of students said that Pancasila education had not supported the development of lawful awareness and behavior because the learning was still cognitively oriented, so a practice was needed so that learning would be more meaningful. Meanwhile, as many as $12 \%$ of students considered that Pancasila learning was quite helpful in building awareness and law-abiding behavior even though in this case it was not optimal.

The success of building legal awareness and law-abiding behavior through Pancasila education in tertiary institutions has many factors influencing. In the learning outcomes themselves, the approach used can affect 
learning outcomes ${ }^{28}$. The smart city embodiment of ethnographic research on the Amsterdam project that encourages citizens to collect and share air quality data concludes that republican citizenship and citizenship $c y$ bernetic provide compelling visions for urban life ${ }^{29}$. In an effort to build legal awareness and law-abiding behavior through Pancasila education is an effort to internalize the values of Pancasila in a person so that they can animate Pancasila. The nation Indonesian as the materialist power of Pancasila ${ }^{30}$, thus determination in realizing Pancasila in attitude and behavior is a must for the Nation Indonesian. With regard to law, the values of Pancasila become das sollen and das sein in an effort to build legal awareness and law-abiding behavior. The law exists to promote social order ${ }^{31}$. Furthermore, the discussion ofideals neoliber$a l$ in favor of participation and citizenship in European smart cities emphasizes that alternative conceptions of smart citizenship need to be used, cities that allow effective transfer of power and are rooted in the rights to cities, community rights, participation rights, collective rights ${ }^{32}$. Building legal awareness and

\footnotetext{
${ }^{28}$ Yayuk Hidayah, Ulfah Nufikha, and Suyitno, “Analisis Pendekatan Pembelajaran Mata Kuliah Wajib Umum Pancasila Dan Pendidikan Kewarganegaraan Di Perguruan Tinggi," JPK: Jurnal Pancasila Dan Kewarganegaraan, 4, no. 1 (2019): 22-33, http:// journal.umpo.ac.id/index.php/JPK/article/view/1361

${ }^{29}$ Dorien Zandbergen and Justus Uitermark, "In Search of the Smart Citizen: Republican and cybernetic citizenship in the Smart City," Urban Studies 57, no.8 (2019): 1733-1748, https://journals.sagepub.com/doi/ full/10.1177/0042098019847410.

${ }^{30}$ Kaelan, Filsafat Pancasila Pandangan Hidup Bangsa Indonesia (Yogyakarta: Paradigma, 2002).

${ }^{31}$ Safudin, Dasar-Dasar Ilmu Hukum.

${ }^{32}$ Paolo Cardullo and Rob Kitchin, "Smart urbanism and smart citizenship: The neoliberal logic of 'citizenfocused' smart cities in Europe," Environment and Planning C: Politics and Space 37, no. 5
}

law-abiding behavior through Pancasila education in Higher Education is a continuation of the concretization of the values contained in Pancasila. Previously, the idea of 'smart city' also led to the idea of 'smart school' in the future of education ${ }^{33}$. Based ondata quantitative , 79\% of students said that learning Pancasila Education in Higher Education was sufficient to support in building awareness and law-abiding behavior. Efforts to build legal awareness and law-abiding behavior through Pancasila education need to be preceded by internalizing the values of Pancasila in everyday life. Strengthening character is an offer in the face of moral decadence ${ }^{34}$. The harmony of life between law and society needs to be resolved so that Pancasila as the basis of the state for the Indonesian nation becomes the basic foundation in legal awareness and lawabiding behavior.

From the quantitative results, the researcher then obtained additional data from interviews with semester 1 students of the Ahmad Dahlan University Sharia Banking Department who stated that during Pancasila Education lectures there was knowledge that could support the development of legal awareness and law-abiding behavior which was realized in the practice of daily life in the form of complying with regulations that apply in

(2018): 813-830, https://journals.sagepub.com/doi/ full/10.1177/0263774X18806508

${ }^{33}$ Ben Williamson, "Educating the Smart City: Schooling Smart Citizens through Computational Urbanism," Big Data and Society, 2, no. 2 (2015): 1-13, https://journals.sagepub.com/doi/ full/10.1177/2053951715617783

${ }^{34}$ Lisa Retnasari, Suyitno, and Yayuk Hidayah, "Penguatan Peran Taman Pendidikan Al-Quran (TPQ) Sebagai Pendidikan Karakter Religius," Jurnal Solma 8, no. 1 (2019): 32-38, https://journal.uhamka.ac.id/ index.php/solma/article/view/2968 
the campus environment and society, prioritizing consensus, and upholding the principle of justice based on Pancasila in good attitudes and actions in the campus environment and society. In learning, the active learning strategy for students can help the memory of students so that learning objectives can be achieved ${ }^{35}$ and the use of appropriate methods can maximize participation in learning ${ }^{36}$

Pancasila Education institutions in Ahmad Dahlan University to support efforts to build legal awareness and behavior. obeying the law, supported by programs that involve students which can have a positive impact on supporting efforts to build legal awareness in the tertiary institution.

Legal awareness and law-abiding behavior through Pancasila education in Higher Education aspiresto obedience to fulfill physical and mental obligations. The result ofreflection theoretical and using smart city politics in Italy has resulted that the smart city discourse proposed by the European Union has been reclassified to produce a new vision of 'good city' and the role of private actors and citizens in managing urban development 37. meanwhile, Smart Cities are often approached by critics as "systems" that exploit

\footnotetext{
${ }^{35}$ Nufikha Ulfah, "Penerapan Pendekatan Active Learning Pada Pendidikan Kewarganegaraan Di Perguruan Tinggi Sebagai Upaya Mengembangkan Kompetensi Kewarganegaraan," in Konferensi Nasional Kewarganegaraan III (Yogyakarta: Universitas Ahmad Dahlan, 2017), 214-225, http:// eprints.uad.ac.id/9784/.

${ }^{36}$ Yayuk Hidayah, "PENGEMBANGAN MODEL BELAJAR KETERLIBATAN (MBK) UNTUK MEMPERKUAT PARTISIPASI POLITIK DAN CIVIC ENGAGEMENT WARGA NEGARA MUDA DI ERA DIGITAL" (Universitas Pendidikan Indonesia, 2020), http://repository.upi.edu/57749/.

${ }^{37}$ Alberto Vanolo, "Smartmentality: The Smart City as Disciplinary Strategy," Urban Studies, 51, no. 5
}

optimal connectivity and efficiency for urban control societies ${ }^{38}$. Legal awareness and lawabiding behavior through Pancasila education in Higher Education produces a character and conscience that is aware of the law. Pancasila as a way of life has become awareness in solving legal problems based on Pancasila ${ }^{39}$. Law was born in providing protection in every dimension of community and state life ${ }^{40}$. Pancasila needs to be ensured to be present in every activity of Indonesian citizens in order to deepen the concept of legal awareness and law-abiding behavior which will further promote law enforcement in Indonesia.

The relevance of Pancasila Education material in Higher Education towards efforts to build legal awareness and lawabiding behavior through Pancasila Education Pancasila Education

Material in Higher Education that is relevant to efforts to build legal awareness and law-abiding behavior through Pancasila education in tertiary institutions is contained in the Pancasila material as an Ethical System , The practice of Pancasila, Pancasila as the basis of the state. In addition, teaching and learning activities carried out by lecturers using various strategies and approaches can be ammunition in an effort to build legal awareness and law-abiding behavior. The findings

(2013): 883-898, https://journals.sagepub.com/doi/ full/10.1177/0042098013494427

${ }^{38}$ Rolien Hoyng, "From Infrastructural Breakdown to Data Vandalism: Repoliticizing the Smart City?," Television \& New Media 17, no. 5 (2005): 397-415, https://journals.sagepub.com/doi/ full/10.1177/1527476415617032

${ }^{39}$ Syahrul Kirom, "Mempraksiskan Pancasila Dalam Penegakan Hukum di Indonesia," Jurnal Ilmiah CIVIS, 5, no. 1 (2005): 654-665, http://journal.upgris. ac.id/index.php/civis/article/view/627

${ }^{40}$ Safudin, Dasar-Dasar Ilmu Hukum. 
of previous research that support these findings are research that investigates the learning approach used in the general compulsory subjects Pancasila and Citizenship Education in Higher Education resulted in that in each different department, a different a p proach is needed in the application of learning the compulsory general Pancasila subject and Citizenship Education in Higher Education ${ }^{41}$. Assessment of Pancasila Education in higher education towards efforts to build legal awareness and law-abiding behavior through Pancasila Education in Higher Education.

Conduct an assessment of efforts to build legal awareness through Pancasila education in Higher Education. There are several aspects that are the focus of the assessment technique, namely. First, the test assessment technique. Assessment of legal awareness tests and lawabiding behavior is carried out during the lecture, divided into written tests, oral tests and practical tests. Based on the three tests, if the review of the indicators of legal awareness shows that students have understood the behavior that has been regulated in the law and regarding the content of the legal material that they have obtained through Pancasila Education which can then be reflected through lawabiding behavior. In the written technique, it appears that students have acquired knowledge of legal awareness. Efforts to build legal awareness through Pancasila education in Higher Education can be identified from the learning experience of students who previously did not know to know about legal awareness and law-abiding behavior.

Second, non-test assessment techniques

\footnotetext{
${ }^{41}$ Hidayah, Nufikha, and Suyitno, "Analisis Pendekatan Pembelajaran Mata Kuliah Wajib Umum Pancasila Dan Pendidikan Kewarganegaraan Di Perguruan Tinggi."
}

in the form of observation, assignments and projects. observations were made of the activities that appeared in the classroom and outside the classroom of the students. By using the indicator of legal awareness, it appears that students have "experienced" an atmosphere of legal awareness. In addition, based on the observations made, it appears that several indicators of legal awareness have been achieved by students. In the assignment assessment, it appears that students have been able to place the values of Pancasila as the basis for efforts to build legal awareness. Even though it is in a simple form, through Pancasila Education, legal awareness efforts have shown results. In project appraisal, students are able to analyze and organize projects related to awareness efforts and law-abiding behavior. Through Pancasila education, the embodiment of citizens who are in accordance with Pancasila by having legal awareness has shown its origins. Thus, through the results of this research, it is found that efforts to build legal awareness need to be carried out continuously.

\section{CONCLUSION}

Building legal awareness and law-abiding behavior through Pancasila Education in Higher Education is an effort to internalize the values of Pancasila in citizens. Student opinion about building legal awareness and law-abiding behavior through Pancasila Education in Higher Education $79 \%$ is sufficient to support in building awareness and lawabiding behavior while as many as $12 \%$ of students think that Pancasila learning is quite helpful in building awareness and law-abiding behavior even though it is not maximal. the relevance of Pancasila Education material in Higher Education towards efforts to build 
legal awareness and law-abiding behavior through Pancasila Education in Higher Education is within the content of Pancasila as an ethical system, Pancasila as a philosophical system, the practice of Pancasila, Pancasila as the state ideology, Pancasila as the basis of the state, Pancasila as a philosophical system. Assessment in Pancasila Education in Higher Education towards efforts to build legal awareness and law-abiding behavior is through test assessments, observations, assignments and projects.

\section{ACKNOWLEDGMENT}

researcher would like to thank all the speakers who were willing to be interviewed. Thank you to all respondents who were willing to fill out the research questionnaire.

\section{BIBLIOGRAPHY}

\section{Books}

Ali, Zainuddin. Filsafat Hukum. Jakarta: Sinar Grafika, 2007.

Asshiddiqie, Jimly and M. Ali Safa'at. Hans Kelsen's Theory of Law. (First printing, Ed.). Jakarta: Sekretariat Jenderal dan Kepaniteraan Mahkamah Konstitusi., 2006.

Az, Lukman Santoso. Negara Hukum Dan Demokrasi: Pasang Surut Negara Hukum Indonesia Pasca Reformasi. Edited by Yutisa Tri Cahyani. Cetakan I. Ponorogo: IAIN Po PRESS, 2016.

Creswell, John W. Research Design: A Qualitative, Quantitative, And Mixed Approach. Yogyakarta: PT Pustaka Pelajar, 2010.

Endsley, Mica R. "Situational Awareness.” In Situational Awareness Edited By Eduardo Salas. London: Routledge, 2011.

Handoyo, Benediktus Hestu Cipto. Hukum Tata Negara Indonesia. Yogyakarta: Atma
Jaya University, 2009.

Kaelan. Filsafat Pancasila Pandangan Hidup Bangsa Indonesia. Yogyakarta: Paradigma, 2002.

Raharjo, Satjipto. Ilmu Hukum. Bandung: PT. Citra Aditya Bakti, 2000.

Safudin, Endrik. Dasar-Dasar Ilmu Hukum. Malang: Setara Press, 2017.

Soekanto, Soerjono. Sosiologi : Suatu Pengantar. Jakarta: CV Rajawali, 1982.

Widjaja, AW. Kesadaran Hukum Manusia Dan Masyarakat Pancasila. Jakarta: CV.Era Swasta., 1982.

\section{Journal}

Cardullo, Paolo and Rob Kitchin. "Smart Urbanism and Smart Citizenship: The Neoliberal Logic of 'Citizen-Focused' Smart Cities in Europe." Environment and Planning C: Politics and Space, 37, no. 5 (2018): 813-830. https://journals.sagepub.com/ doi/full/10.1177/0263774X18806508.

Hasibuan, Zulkarnain. "Kesadaran Hukum Dan Ketaatan Hukum Masyarakat Dewasa Ini." Jurnal Justitia: jurnal Ilmu Hukum Dan Humaniora 1, no. 1 (2013): 78-92. http://jurnal.um-tapsel.ac.id/index.php/ Justitia/article/view/40.

Hastjarjo, Dicky. "Sekilas Tentang Kesadaran (Consciousness)." Buletin Psikologi 13, no. 2 (2015): 79-90. https://jurnal.ugm. ac.id/buletinpsikologi/article/view/7478

Hidayah, Yayuk, Ulfah Nufikha, and Suyitno.

"Analisis Pendekatan Pembelajaran Mata Kuliah Wajib Umum Pancasila Dan Pendidikan Kewarganegaraan Di Perguruan Tinggi." JPK: Jurnal Pancasila Dan Kewarganegaraan 4, no. 1 (2019): 22-33. http://journal.umpo.ac.id/index.php/JPK/ article/view/1361

Hidayah, Yayuk, Meiwatizah Trihastuti, and Dinie Anggraeni Dewie. "Kecerdasan 
Berideologi Calon Guru Pendidikan Sekolah Dasar Melalui Pendidikan Pancasila." Jurnal Al - Qiyam 2, no. 1 (2020): 74. https://journal.stai-alfurqan.ac.id/alqiyam/ index.php/alqiyam/

Hoyng, Rolien. "From Infrastructural Breakdown to Data Vandalism: Repoliticizing the Smart City?." Television \& New Media 17, no. 5 (2005): 397415. https://journals.sagepub.com/doi/ full/10.1177/1527476415617032.

Kamaruddin. "MEMBANGUN KESADARAN DAN KETAATAN HUKUM MASYARAKAT PERSPEKTIF LAW ENFORCEMENT." Jurnal Al-'Adl, 9, no. 2 (2016): 143-157. https://ejournal.iainkendari.ac.id/index.php/al-adl/article/ view/683

Kirom, Syahrul. "Mempraksiskan Pancasila Dalam Penegakan Hukum Di Indonesia." Jurnal Ilmiah CIVIS 5, no. 1 (2005): 654665. http://journal.upgris.ac.id/index.php/ civis/article/view/627.

Kuncorowati, Puji Wulandari. "Menurunnya Tingkat Kesadaran Hukum Masyarakat Di Indonesia." Jurnal Civics Media Kajian Kewarganegaraan 4, no.2 (2009) : 74-75. https://journal.uny.ac.id/index.php/civics/ article/view/5678.

Retnasari, Lisa, Suyitno, and Yayuk Hidayah. "Penguatan Peran Taman Pendidikan Alquran ( TPQ ) Sebagai Pendidikan Karakter Religius." Jurnal Solma 8, no. 1 (2019): 32-38. https://journal.uhamka. ac.id/index.php/solma/article/view/2968.

Rosana, Ellya. "Kepatuhan Hukum sebagai Wujud Kesadaran Hukum Masyarakat." Jurnal Tapis: Jurnal Teropong Aspirasi Politik Islam 10, no. 1 (2014): 2, http:// ejournal.radenintan.ac.id/index.php/TAPIs/article/view/1600.
Setyawan, Heru, and Indri Fogar Susilowati. "KESADARAN HUKUM MAHASISWA TERHADAPATURAN TENTANG AREA KAWASAN TANPA ROKOK (Studi Di Kampus Universitas Negeri Surabaya)." Novum: Jurnal Hukum 5, no. 3 (2018): 48-55. https://ejournal.unesa.ac.id/index. php/novum/article/view/36058.

Soekanto, Soerjono. "Kesadaran Hukum Dan Kepatuhan Hukum." Jurnal Hukum Dan Pembangunan, 7, no. 6 (1977) 462-470. http://jhp.ui.ac.id/index.php/home/article/ view/742.

Ulfah, Nufikha, Yayuk Hidayah, Mirza Hardian, and Meiwatizal Trihastuti. "PROJECT CITIZEN: DEVELOPMENT OF SOCIAL SKILLS AND UNDERSTANDING OF CONTEMPORARY ISSUES (STUDY AT AHMAD DAHLAN UNIVERSITY)." Lentera Pendidikan : Jurnal Ilmu Tarbiyah dan Keguruan 23, no. 1 (2020): 9-21. http://journal.uin-alauddin.ac.id/ index.php/lentera_pendidikan/article/ view/12520.

Vanolo, Alberto. "Smartmentality: The Smart City as Disciplinary Strategy." Urban Studies 51, no. 5 (2013): 883898. https://journals.sagepub.com/doi/ full/10.1177/0042098013494427.

Williamson, Ben. "Educating the Smart City: Schooling Smart Citizens through Computational Urbanism." Big Data and Society 2, no. 2(2015): 1-13. https://journals.sagepub. com/doi/full/10.1177/2053951715617783.

Zandbergen, Dorien and Justus Uitermark. "In Search of the Smart Citizen: Republican and Cybernetic Citizenship in the Smart City." Urban Studies 57, no.8 (2019): 1733-1748. https://journals.sagepub.com/ doi/full/10.1177/0042098019847410. 


\section{Internet}

Setiawan, Ebta. "KBBI Online." Badan Pengembangan Dan Pembinaan Bahasa. Last modified 2012. https://kbbi.web.id/ sadar.

\section{Proceedings}

Mahfiana, Layyin. "Kesadaran Hukum Mahasiswa Terhadap Teknologi Dan Perkembangannya." In Prosiding Seminar $\mathrm{Na}$ sional \& Temu Ilmiah Jaringan Peneliti IAI Darussalam Blokagung Banyuwangi, 1-13. Banyuwangi: IAI Darussalam Blokagung Banyuwangi, 2017. http:// ejournal.iaida.ac.id/index.php/proceeding/ article/view/179.

Sumaryati. "Urgensi Pendidikan Hukum Dalam Mewujudkan Kesadaran Hukum Masyarakat." In Konferensi Kewarganegaraan, 1-13. Yogyakarta: Universitas Negeri Yogyakarta, 2015. http://eprints. uad.ac.id/8071/.

Ulfah, Nufikha. "Penerapan Pendekatan Active Learning Pada Pendidikan Kewarganegaraan Di Perguruan Tinggi Sebagai Upaya Mengembangkan Kompetensi Kewarganegaraan." In Konferensi Nasional Kewarganegaraan III, 214-225. Yogyakarta: Universitas Ahmad Dahlan, 2017. http://eprints.uad.ac.id/9784/.

\section{Thesis}

Fuad, Iwan Zainul. "Kesadaran Hukum Pengusaha Kecil Di Bidang Pangan Dalam Kemasan Di Kota Semarang Terhadap Regulasi Sertifikasi Produk Halal.” Magister Ilmu Hukum Universitas Diponegoro, 2010. http://eprints.undip. ac.id/23888/.

Hidayah, Yayuk. "PENGEMBANGAN MODEL BELAJAR KETERLIBATAN (MBK) UNTUK MEMPERKUAT PARTISIPASI POLITIK DAN CIVIC
ENGAGEMENT WARGA NEGARA MUDA DI ERA DIGITAL." Universitas Pendidikan Indonesia, 2020. http:// repository.upi.edu/57749/.

Jubaedi, Dedi Ahmad. "Kesadaran Hukum Mahasiswa Terhadap UU RI No. 11 Tahun 2008 Tentang Informasi Dan Transaksi Elektronik Dalam Penggunaan Internet." Fakultas Pendidikan Ilmu Pengetahuan Sosial Universitas Pendidikan Indonesia, 2016. http://repository.upi. edu/26460/. 